\section{'Mountain Rouge': A Pink-fruited, Heirloom-type Hybrid Tomato and Its Parent Line NC 161L}

\author{
Dilip R. Panthee ${ }^{\mathbf{1}}$ and Randy G. Gardner \\ Department of Horticultural Science, North Carolina State University, \\ Mountain Horticultural Crops Research and Extension Center (MHCREC), \\ 455 Research Drive, Mills River, NC 28759-3423
}

Additional index words. fresh-market tomato, heirloom tomato, improved flavor, indeterminate growth, late blight resistance, root-knot nematodes resistance, Solanum lycopersicum

'Mountain Rouge' is an improved heirloom-type $\mathrm{F}_{1}$ hybrid tomato (Solanum lycopersicum L.) with large, smooth, pink fruit, excellent flavor, and an indeterminate growth habit. It is resistant to late blight [Phytophthora infestans (Montagne, Bary)] and root knot nematodes (Meloidogyne spp).

\section{Origin}

'Mountain Rouge', the $\mathrm{F}_{1}$ hybrid of NC $161 \mathrm{~L} \times$ 'Pink Brandywine' (Fig. 1), resulted from a tomato breeding effort initiated in 2005 to develop a superior heirloom-type, pink-fruited tomato hybrid with improved fruit quality and late blight resistance. 'Mountain Rouge' (tested as NC 08224) was first crossed in the spring of 2008 and was grown in an observational trial at the Piedmont Research Station, Salisbury, NC, in the fall of 2008. Based on its favorable performance in that trial, it was selected for more advanced testing. It was grown in replicated trials at the Mountain Research Station (MRS), Waynesville, NC, in 2009 and 2011 and has been widely tested in grower plantings in western North Carolina and the northeastern United States. The MRS, Waynesville, is a high-elevation area in North Carolina and is suitable for late blight testing.

The development of parent line NC 161L began when a cross was made in the fall of 2005 between NC 2CELBR and TB (x)-9, an $\mathrm{F}_{2}$ selection of the Japanese pink-fruited, greenhouse hybrid tomato 'Momotaro' ('Tough Boy'). NC 2CELBR was the source of the $P h-2$ and $P h-3$ genes for late blight resistance (Gardner and Panthee, 2010) in the NC 161L parent line. An $F_{2}$ population from the resultant cross, NC 0652, was grown in the field during the summer season of 2006 and selected for late blight resistance and desirable horticultural traits, including pink

Received for publication 23 June 2014. Accepted for publication 7 Aug. 2014.

The tomato breeding program of North Carolina State University was supported by the North Carolina Tomato Growers Association and the Hatch project of the USDA.

${ }^{1}$ To whom reprint requests should be addressed; e-mail dilip_panthee@ncsu.edu. fruit color. An $\mathrm{F}_{3}$ generation selection, 161L1W (2007), with desirable horticultural traits and a high level of late blight resistance was made in the field in 2007. A subsequent $F_{4}$ generation selection was made in the greenhouse to develop the line NC0652(x)-1W-1W-1, which was bulked and subsequently released as NC 161L.

\section{Description}

Performance of 'Mountain Rouge' (NC 08224) was compared with common heirloom varieties 'Cherokee Purple', 'Pink Brandywine', and 'Mr. Stripey'. In an organic culture trial in 2009 where late blight was severe in the latter part of the season, 'Mountain Rouge' was significantly higher than the heirloom varieties in total and marketable yields (Table 1). 'Mountain Rouge' was highly resistant to late blight, whereas the heirloom varieties were destroyed by late blight in the last half of the harvest season (Table 1). In an organic trial where late blight was not present, 'Mountain Rouge' was equivalent or higher than the named heirloom varieties in total yield but did not differ from them in marketable yield (Table 2). The percent marketable yield of 'Mountain Rouge' and 'Pink Brandywine' was low in this trial because of severe fruit cracking, typical of most pink-fruited tomatoes. Fully ripe fruit were harvested only one time per week, which may have increased the fruit cracking. Commercial growers harvest two or three times per week typically resulting in fewer fruit cracking. 'Mountain Rouge' has performed

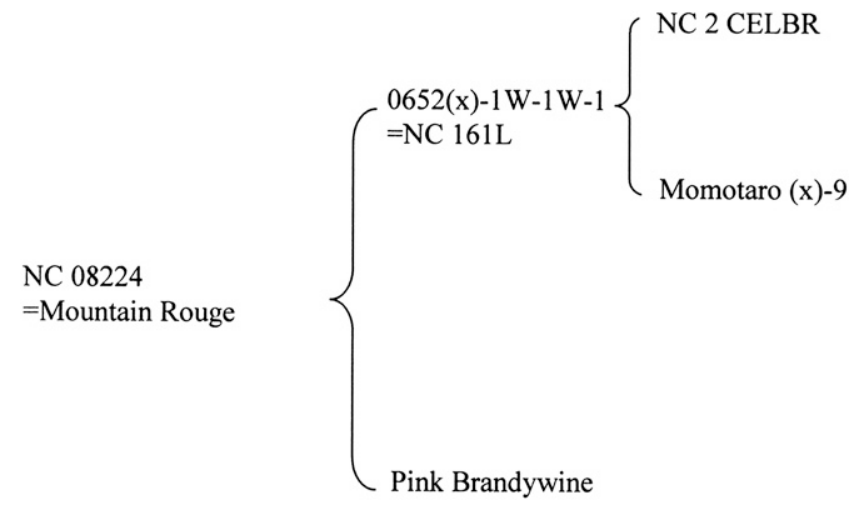

Fig. 1. Pedigree of NC 161L and 'Mountain Rouge' (NC 08224) hybrid tomato. well in numerous observational trials in research stations and grower fields in multiple states including Florida, North Carolina, South Carolina, and Tennessee.

Fruit of 'Mountain Rouge' ripens to an attractive pink color and are more firm in the fully ripe stage than similar heirloom tomatoes. The fruits are deep oblate and slightly irregular in shape with small, well-healed blossom-end scars. Fruits are significantly smoother than their heirloom parent 'Pink Brandywine'. Immature fruits have a dark green shoulder color. Flavor and fruit texture of 'Mountain Rouge' have been rated as excellent in subjective taste evaluations in research station plots and in growers' trial plots.

'Mountain Rouge' has a vigorous vine with an indeterminate growth habit. Foliage is green in color and provides adequate coverage for fruit protection. When evaluated under natural inoculum pressure of root-knot nematode (RKN) in field plots in 2010 at Mills River, NC, 'Mountain Rouge' and NC $161 \mathrm{~L}$ were both highly resistant to RKN compared with 'Pink Brandywine', which had severe root galls. The Mi gene conferring RKN resistance in $\mathrm{NC} 161 \mathrm{~L}$ originated from a 'Momotaro' hybrid, which has RKN resistance. Based on disease resistance genes present in the parent lines of NC 161L, 'Mountain Rouge' is expected to be heterozygous for the $I$ gene conferring resistance to race 1 of fusarium wilt and heterozygous for the $V e$ gene conferring resistance to verticillium wilt. However, presence of these two resistance genes has not been confirmed. Despite its susceptibility to fruit cracking, 'Mountain Rouge' was released for its superior late blight and RKN resistance and its outstanding flavor comparable to several heirloom varieties.

Presence of the $P h-3$ and $M i$ genes for resistance to late blight and $\mathrm{RKN}$, respectively, were verified by molecular markers tightly linked to the resistance genes (Fig. 2).

In a conventional culture trial at Mills River, NC, in 2010, NC 161L performed well in comparison with the inbred lines NC 714 and NC 1CS, which are the parents of the recently released hybrid 'Mountain Majesty' (Panthee and Gardner, 2011). NC 161L was smaller-fruited than either of control lines (Table 3). In an organic culture, replicated trial in 2011 , NC $161 \mathrm{~L}$ performed extremely well in marketable yield compared with 
Table 1. Performance of 'Mountain Rouge' and three heirloom tomato varieties under organic production conditions with heavy pressure of late blight at the Mountain Research Station, Waynesville, NC (2009).

\begin{tabular}{lcccccc}
\hline Variety & $\begin{array}{c}\text { Total yield } \\
\left(\mathrm{t} \cdot \mathrm{ha}^{-1}\right)^{\mathrm{z}}\end{array}$ & $\begin{array}{c}\text { Marketable yield } \\
\left(\mathrm{t} \cdot \mathrm{ha}^{-1}\right)\end{array}$ & $\begin{array}{c}\text { Marketable } \\
(\%)\end{array}$ & $\begin{array}{c}\text { Fruit } \\
\text { wt }(\mathrm{g})\end{array}$ & $\begin{array}{c}\text { Fruit cracking } \\
(\%)\end{array}$ & $\begin{array}{c}\text { Late blight } \\
\text { score }^{\mathrm{y}}\end{array}$ \\
\hline Mountain Rouge & 49 & 36 & 73 & 329 & 73 & 0.0 \\
Cherokee Purple & 30 & 20 & 67 & 298 & 63 & 4.8 \\
Pink Brandywine & 38 & 23 & 61 & 467 & 55 & 4.8 \\
Mr. Stripey & 32 & 16 & 50 & 580 & 64 & - \\
LSD $_{(0.05)}$ & 4 & 4 & 16 & 122 & 16 & - \\
\hline
\end{tabular}

${ }^{\mathrm{z}}$ All values are average of two replicates.

${ }^{\mathrm{y}}$ Incidence of late blight was evaluated on a scale of 0 (completely healthy) to 5 (entire plant destroyed by late blight.

LSD $=$ least significant difference.

Table 2. Performance of 'Mountain Rouge' and three heirloom tomato varieties under organic production conditions with no late blight at the Mountain Research Station, Waynesville, NC (2011).

\begin{tabular}{lccccc}
\hline Variety & $\begin{array}{c}\text { Total yield } \\
\left(\mathrm{t} \cdot \mathrm{ha}^{-1}\right)^{\mathrm{z}}\end{array}$ & $\begin{array}{c}\text { Marketable yield } \\
\left(\mathrm{t} \cdot \mathrm{ha}^{-1}\right)\end{array}$ & $\begin{array}{c}\text { Marketable } \\
(\%)\end{array}$ & $\begin{array}{c}\text { Fruit } \\
\text { wt }(\mathrm{g})\end{array}$ & $\begin{array}{c}\text { Fruit cracking } \\
(\%)\end{array}$ \\
\hline Mountain Rouge & 157 & 31 & 20 & 284 & 72 \\
Cherokee Purple & 155 & 36 & 23 & 286 & 66 \\
Pink Brandywine & 137 & 32 & 23 & 454 & 63 \\
NC 161L & 141 & 63 & 45 & 199 & 50 \\
LSD $_{(0.05)}$ & 3 & 8 & 15 & 102 & 15 \\
\hline
\end{tabular}

${ }^{\mathrm{z}}$ Data are an average of two replicates.

$\mathrm{LSD}=$ least significant difference.

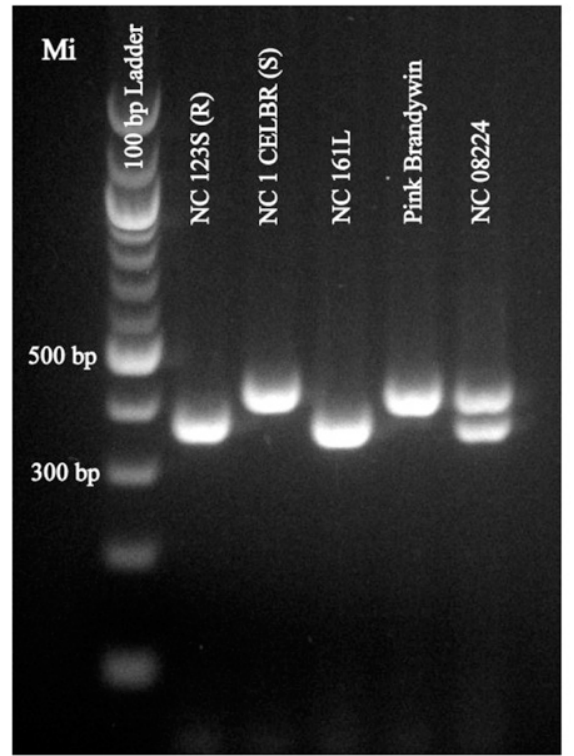

A

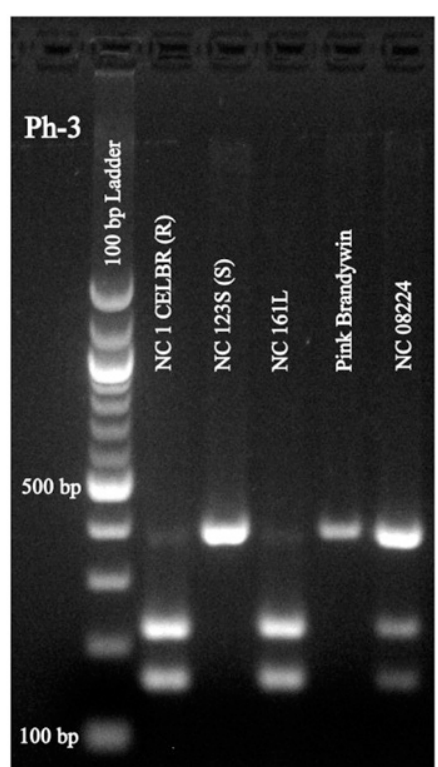

B

Fig. 2. Molecular screening of NC 161L and 'Mountain Rouge' (NC 08224) for (A) Mi gene (root knot nematode resistance) and (B) $P h-3$ gene (late blight resistance). Molecular marker screening indicated that 'Mountain Rouge' was heterozygous for $M i$ and $P h-3$ genes.

Table 3. Performance of NC161L tomato breeding line in a conventional trial at Mountain Horticultural Crops Research and Extension Center, Mills River, NC (2010).

\begin{tabular}{lcccr}
\hline Genotype & $\begin{array}{c}\text { Total yield } \\
\left(\mathrm{t} \cdot \mathrm{ha}^{-1}\right)\end{array}$ & $\begin{array}{c}\text { Marketable yield } \\
\left(\mathrm{t} \cdot \mathrm{ha}^{-1}\right)\end{array}$ & Marketable (\%) & Fruit wt. (g) \\
\hline NC 1 CS & 116 & 95 & 81 & 371 \\
NC 714 & 133 & 61 & 46 & 328 \\
NC 161L & 115 & 82 & 71 & 288 \\
LSD $_{(0.05)}$ & 19 & 19 & 8 & 40 \\
\hline
\end{tabular}

LSD $=$ least significant difference.

'Cherokee Purple' and 'Pink Brandywine' (Table 2). Its total yield did not differ from the other entries in the trial, but its marketable yield was much higher because of substantially less fruit cracking and other fruit defects.
NC 161L has a vigorous, tall-growing determinate plant ( $s p$ gene) with good foliage cover for fruit protection. Fruit are deep oblate in shape and symmetrical with smooth blossom-end scars and smooth shoulders. Immature fruit have a dark green shoulder color, and fruit pedicels are jointed. The fruits develop an attractive pink surface color when ripe and are moderately firm. Flavor of NC 161L has been rated as good in subjective taste tests. NC $161 \mathrm{~L}$ is moderately susceptible to radial fruit cracking under field growing conditions.

A high level of late blight resistance is present in NC 161L based on the presence of $P h-2$ and $P h-3$ genes and its field trials at Waynesville, NC, in 2006 and 2007 where late blight was severe in both years. A high level of late blight resistance was also observed in an organic trial at Waynesville, NC, in 2009 in the $\mathrm{F}_{1}$ hybrids NC 08144 and 'Mountain Rouge', both of which use NC 161L as a parent. Presence of $P h-3$ and $M i$ genes in NC 161L was confirmed by molecular markers tightly linked to the genes (Fig. 2). Based on disease resistance genes present in both of its parents, NC 161L should be homozygous for the $I$ gene for resistance to race 1 of fusarium wilt and for the $V e$ gene for verticillium wilt resistance. However, these resistances have not been verified.

\section{Use}

'Mountain Rouge' provides growers in North Carolina and other states with similar growing conditions a high-yielding, diseaseresistant, fresh-market tomato cultivar with good fruit quality and similarities to widely grown pink-fruited heirloom varieties. The combined resistances to late blight and RKNs are valuable additions in disease resistance for growing areas where these diseases are a problem. NC 161L should also be of interest to other tomato breeders as a single source of combined resistances to important tomato diseases and nematodes. NC 161L's desirable combination of plant, fruit quality, and disease resistance traits should make it useful in further breeding of pink tomatoes and as a parent in developing other pink-fruited tomato hybrids with late blight and RKN resistances.

\section{Availability}

'Mountain Rouge' was released on an exclusive basis for seed production and sales to Bejo Seeds, and commercial seed should be available in 2015. Distribution of seed of NC 161L to other breeders requires a signed seed transfer agreement, which can be downloaded at the following web site: $<$ http://www.mountainhort.ncsu.edu/programs/ tomato/releases/tomato-seed-transfer-agreement. pdf $>$. Small trial samples of 'Mountain Rouge' are available from D.R. Panthee (dilip panthee@ncsu.edu), MHCREC, 455 Research Drive, Mills River, NC 28759.

\section{Literature Cited}

Gardner, R.G. and D.R. Panthee. 2010. NC 1 CELBR and NC 2 CELBR: Early blight and late blight resistant fresh market tomato breeding lines. HortScience 45:975-976.

Panthee, D.R. and R.G. Gardner. 2011. 'Mountain Majesty': A tomato spotted wilt virus-resistant fresh-market hybrid tomato and its parents $\mathrm{NC}$ 714 and NC 1CS. HortScience 46:1321-1323. 